\title{
Użyteczność informacji w sprawozdaniu finansowym w kontekście epidemii w związku z zakażeniami wirusem SARS-CoV-2
}

Usefulness of the information in the financial statements in the context of the SARS-CoV-2 infection epidemic

\section{Wprowadzenie}

Sprawozdanie finansowe jest dokumentem obligatoryjnie sporządzanym przez jednostki prowadzące rachunkowość i mimo, że są różne formy oraz metody ujawniania informacji, wśród nich sprawozdanie wyróżnia się najbardziej (Hendriksen, Van Breda, 2002, s. 868). Zawiera informacje historyczne przedstawione na dzień bilansowy kończący rok obrotowy, ale odnosi się również do tych po dacie bilansu, aż do dnia sporządzenia sprawozdania finansowego. Ten powinien przypaść nie później niż w ciągu 3 miesięcy od dnia bilansowego. W 2020 r. w związku z epidemią spowodowaną infekcją SARS-CoV-2 dokonano zmiany w regulacjach rachunkowości polegającej na wydłużeniu tego terminu o 2 lub 3 miesiące zależnie od rodzaju jednostki. Mogły one dokonać ustalenia tego terminu w czasie nawet 6 miesięcy od dnia bilansowego. Regulacja ta jest jednorazowa, jak należy sądzić, a jej zastosowanie zależy od konkretnej sytuacji jednostki w zakresie przyjętego roku obrotowego. Niemniej większość jednostek w Polsce ma rok obrotowy zgodny z kalendarzowym. Zatem dzień ogłoszenia stanu epidemii, a także związane z tym ograniczenia utrudniające funkcjonowanie jednostek, które skutkują efektami finansowymi, pojawiły się nieco przed pierwotnym terminem przygotowania sprawozdania finansowego większości jednostek. Informacje o zbliżającej się sytuacji można było widzieć, a nawet wobec globalizacji - odczuwać, już od końca 2019 r. Zdarzenie ogłoszenia stanu epidemii mogło mieć miejsce w różnym okresie wykonywania kolejnych 
czynności w zakresie sporządzenia sprawozdania finansowego. Zgodnie z regulacjami jednostki powinny analizować zdarzenia, które mogą mieć znaczenie dla przygotowywanego sprawozdania finansowego również po dacie bilansu, co najmniej do dnia jego sporządzenia (Ustawa z dnia 29 września $1994 \mathrm{r}$. o rachunkowości, 2019, art. 5 ust. 2, art. 7 ust. 2, art. 54). Skoro tak, trzeba te zdarzenia zidentyfikować, ocenić i zakwalifikować jako istotne lub nie, korygujące sprawozdanie finansowe lub nie, wymagające ujawnienia w formie opisowej lub nie. Te wymogi wykonania konkretnych czynności i ocen doprowadziły do sformułowania pytania badawczego: jak jednostki odnotowały ogłoszenie epidemii i wynikające $z$ tego kolejne zdarzenia w sprawozdaniu finansowym. Postawiono ogólne pytanie o użyteczność informacji w sprawozdaniu finansowym. Ta cecha wymaga dzisiaj badania w kontekście sporządzania sprawozdania finansowego w sytuacji globalnego kryzysu gospodarczego. W związku z tym dokonano przeglądu regulacji dotyczących wprowadzenia stanu epidemii i rachunkowości, w szczególności zdarzeń po dacie bilansu, oraz zmian w regulacjach rachunkowości w związku z wprowadzeniem epidemii. Obiektem badań były również przykładowe sprawozdania finansowe, $w$ których szukano informacji o wpływie sytuacji epidemicznej na sytuację majątkowo-finansową i wynik finansowy jednostki, a także badano sposób wypełnienia wymogów informacyjnych. Trzeba tu dodać, że nadal wielu czytelników sprawozdań finansowych analizuje je jako źródło informacji o przeszłości. Obecnie to jednak analiza możliwości przetrwania jest kluczowa, co powoduje, że należy w sprawozdaniach finansowych szukać również informacji o przyszłych i potencjalnych zagrożeniach dla kontynuowania działalności, których podanie jest przecież wymagane przez regulacje.

Samo zagadnienie zakresu informacji o przyszłości prezentowanych w sprawozdaniu finansowym jest problematyczne i różnie określa się, co jeszcze stanowi wierną i rzetelną informację, a co jest obarczone zbyt dużym stopniem niepewności i już nie powinno być formułowane jako stwierdzenie w sprawozdaniu. Dlatego decyzja o tym, czy ujawniać taką informację, jest trudna i musi być podjęta $\mathrm{z}$ dużą dozą ostrożności, a przede wszystkim z uwzględnieniem konieczności zapewnienia cechy rzetelności i jasności. Informacja o wpływie epidemii na sytuację jednostki też wymaga takiej decyzji. Również oczekiwanie co do tego, jak ujawnienie powinno wyglądać, może się różnić u różnych interesariuszy. Stąd niektóre kwestie zawarte w tym artykule mogą być dyskusyjne dla poszczególnych czytelników. Niemniej jednak, mimo tej dyskusyjności, sprawozdanie finansowe to nie tylko obraz faktów, ale i świadectwo podmiotu sporządzającego o jego podejściu do zagadnienia. Badania krytyczne regulacji, literatury przedmiotu i przykładowych sprawozdań finansowych oraz wniosko- 
wanie metodą indukcji i dedukcji pozwoliły na ocenę wypełnienia obowiązków i na kilka wstępnych wniosków, będących przyczynkiem do dalszych badań. Powstała hipoteza, że sprawozdania finansowe sporządzane w czasie obecnego kryzysu nie są wystarczająco użyteczne w zakresie ujawnień co do przyszłych zagrożeń dla kontynuacji działalności. Oczywiście odnośnie do ewentualnych przyczyn takiego stanu trzeba odrębnych badań, a tu wystarczy podkreślić, że brak tej użyteczności nie musi oznaczać braku woli jej zapewnia i należytej staranności w tym względzie. Może on być uzasadniony wieloma czynnikami, np. tym, że jednostki nie były w stanie zrobić odpowiednich analiz sytuacji - znów z różnych powodów. Być może je zrobiły, ale ich wyników nie ujawniły jako obarczonych zbyt wysoką niepewnością, ważąc rzetelność informacji i w efekcie podchodząc do tego zdarzenia bardzo ogólnie. Być może również okoliczności, w jakich odbierana jest informacja, powodują, że traci ona cechę użyteczności. Niewątpliwie natomiast użyteczność informacji w przypadku wystąpienia stanu epidemii zależy od tego, na jaki dzień i kiedy względem dnia jego ogłoszenia jednostki sporządzają sprawozdanie finansowe. Trudno jest - wobec różnorodności przypadków w tym obszarze - dokonywać porównawczych analiz jednostek w zakresie przedmiotowych informacji. Natomiast ocenianie zmian danych finansowych będzie możliwe dopiero za rok, kiedy zmaterializują się już w nich przynajmniej w jakimś zakresie skutki gospodarcze. Tymczasem użytkownicy sprawozdań muszą liczyć na odpowiedzialność jednostek, społeczną odpowiedzialność w zakresie przygotowania i prezentowania informacji. Zachowanie jej w sytuacji epidemii jest poniekąd praktycznym wyrazem deklarowanych wartości i zasad weryfikowanych w sytuacji szczególnej i trudnej.

\section{Wprowadzenie stanu epidemii w Polsce a rachunkowość}

Wprowadzenie stanu epidemii w Polsce wywołało określone konsekwencje w wielu obszarach życia, w tym również w prowadzeniu rachunkowości. Wpłynęło bezpośrednio na wykonanie obowiązku sporządzenia i zatwierdzenia, a co za tym idzie - upublicznienia sprawozdania finansowego. Skutki wprowadzonego stanu dla wypełnienia tych obowiązków dotyczyły m.in. uwzględniania zdarzeń do dnia jego sporządzenia (ewentualnie przesuniętego), a następnie analogicznie do dnia jego zatwierdzenia (również przesuniętego). Każda jednostka ma prawo ustalić dzień bilansowy w dowolnym dniu roku kalendarzowego i w zależności od niego można określić ostateczny dzień sporządzenia sprawozdania 
finansowego. W tym szczególnym 2020 r. interwał między tymi dniami został wydłużony nawet podwójnie, a tym samym jednostki mogły mieć nawet pół roku na sporządzenie sprawozdania finansowego. Położenie dnia sporządzenia względem dnia bilansowego wyznaczyło okres obserwacji zdarzeń po dniu bilansowym - jeśli termin sporządzenia sprawozdania finansowego wydłużył się, okres obserwacji wystąpienia tych zdarzeń jest proporcjonalnie dłuższy. W różnym położeniu w stosunku do dni ograniczających te okresy, czyli dnia bilansowego, sporządzenia i zatwierdzenia sprawozdania finansowego, wystąpić mógł w danej jednostce dzień ogłoszenia stanu epidemii. To determinuje, jaki wpływ na zawartość informacyjną sprawozdania finansowego mogło mieć wprowadzenie tego stanu z jego konsekwencjami. Zobrazowanie tego wymaga przedstawienia odpowiednich regulacji.

Rozporządzenie Ministra Zdrowia, które weszło w życie 20 marca 2020 r., określiło, że „W okresie od dnia 20 marca 2020 r. do odwołania na obszarze Rzeczypospolitej Polskiej ogłasza się stan epidemii w związku z zakażeniami wirusem SARS-CoV-2." (Rozporządzenie Ministra Zdrowia z dnia 20 marca 2020 r., 2020). Z kolei ustawa (Ustawa $z$ dnia 2 marca 2020 r., 2020) obowiązująca od 8 marca 2020 r. wprowadziła obowiązkową hospitalizację i kwarantannę lub nadzór epidemiologiczny. Dnia 31 marca 2020 r. Minister Finansów wydał rozporządzenie (Rozporządzenie Ministra Finansów z dnia 31 marca 2020 r., 2020), w którym określił inne terminy wypełniania obowiązków w zakresie ewidencji oraz w zakresie sporządzenia, zatwierdzenia, udostępnienia i przekazania do właściwego rejestru, jednostki lub organu sprawozdań lub informacji. Dla większości jednostek wydłużono terminy o 3, dla niektórych o 2 miesiące. Powstałe w następstwie tego zmiany dotyczą okresu identyfikacji i oceny zdarzeń mających miejsce po dniu bilansowym. Istnieje ustawowy (Ustawa z dnia 29 września $1994 \mathrm{r}$. o rachunkowości, 2019, art. 54) obowiązek analizy zdarzeń po dacie bilansu do dnia sporządzenia, a następnie do dnia zatwierdzenia sprawozdania finansowego, z określonymi konsekwencjami. Te polegać mogą na:

- ujęciu zdarzenia w księgach rachunkowych i przygotowywanym sprawozdaniu finansowym za poprzedni okres lub dopiero za okres bieżący,

- ujawnieniu dodatkowych informacji o zdarzeniu w przygotowywanym sprawozdaniu finansowym w formie narracji,

- zmianie zasad wyceny majątku w przygotowywanym sprawozdaniu finansowym.

Zapisy nakazujące takie zachowanie to art. $54 \mathrm{i}$ art. 29 ustawy o rachunkowości (Ustawa z dnia 29 września 1994 r. o rachunkowości, 2019). Pierwszy artykuł wskazuje, jak postąpić w razie otrzymania informacji o zdarzeniach, które mają 
istotny wpływ na przygotowywane sprawozdanie finansowe lub powodujących, że założenie kontynuowania działalności przez jednostkę nie jest uzasadnione.

Jeżeli po sporządzeniu rocznego sprawozdania finansowego, a przed jego zatwierdzeniem, jednostka otrzymała informacje o zdarzeniach, które mają istotny wpływ na to sprawozdanie finansowe, lub powodujących, że założenie kontynuowania działalności przez jednostkę nie jest uzasadnione, powinna ona odpowiednio zmienić to sprawozdanie, dokonując jednocześnie odpowiednich zapisów w księgach rachunkowych roku obrotowego, którego sprawozdanie finansowe dotyczy, oraz powiadomić biegłego rewidenta, który sprawozdanie to bada lub zbadał. Jeżeli zdarzenia, które nastąpiły po dniu bilansowym, nie powodują zmiany stanu istniejącego na dzień bilansowy, to odpowiednie wyjaśnienia zamieszcza się w informacji dodatkowej. Jeżeli jednostka otrzymała informacje o zdarzeniach, [...] po zatwierdzeniu rocznego sprawozdania finansowego, to ich skutki ujmuje w księgach rachunkowych roku obrotowego, w którym informacje te otrzymała (Ustawa z dnia 29 września 1994 r. o rachunkowości, 2019, art. 54).

Drugi artykuł mówi, jak się zachować, jeżeli założenie kontynuacji działalności nie jest zasadne. Samo założenie wynika z art. 5 ust. 2 ustawy.

Przy stosowaniu przyjętych zasad (polityki) rachunkowości przyjmuje się założenie, że jednostka będzie kontynuowała w dającej się przewidzieć przyszłości działalność w niezmniejszonym istotnie zakresie, bez postawienia jej w stan likwidacji lub upadłości, chyba że jest to niezgodne ze stanem faktycznym lub prawnym. Ustalając zdolność jednostki do kontynuowania działalności, kierownik jednostki uwzględnia wszystkie informacje dostępne na dzień sporządzenia sprawozdania finansowego, dotyczące dającej się przewidzieć przyszłości, obejmującej okres nie krótszy niż jeden rok od dnia bilansowego (Ustawa z dnia 29 września 1994 r. o rachunkowości, 2019, art. 5 ust. 2).

Biorąc pod uwagę powyższe, należało $\mathrm{w}$ rachunkowości każdej jednostki przeanalizować sytuację w zakresie wpływu wprowadzenia stanu epidemii na kontunuowanie przez nią działalności i określić, czy wprowadzenie stanu epidemii jest w jej przypadku zdarzeniem po dniu bilansowym o charakterze korygującym stan na dzień bilansowy, czy nie. Następnie ewentualnie należało 
odpowiednio ująć jego skutki lub zamieścić stosowne informacje we właściwych częściach sprawozdania finansowego, ujawniając wpływ (nawet potencjalny i szacunkowy) tego zdarzenia na sytuację jednostki. Informacja ta w efekcie trafia do czytelnika, który ocenia jej użyteczność oraz czy jest w stanie zorientować się na jej podstawie w sytuacji jednostki w zakresie zagrożeń dla kontynuacji działalności, w szczególności we wpływie epidemii na tę sytuację. Ocena taka została dalej przeprowadzona na trzech przykładach.

\section{Praktyka w zakresie ujawniania informacji - analiza przypadków}

Analizie poddano sprawozdania finansowe za 2019 r. sporządzone na dzień 31 grudnia 2019 r. trzech przykładowych jednostek, wybranych z bazy EKRS spośród spółek akcyjnych mających siedzibę w województwie świętokrzyskim, których sprawozdania finansowe były dostępne w ostatniej dekadzie sierpnia 2020 r. w formacie możliwym do odczytania ${ }^{1}$. Oczekiwano, na podstawie analizy regulacji rachunkowości, wśród których oprócz ustawy o rachunkowości są również krajowe standardy rachunkowości, znaleźć w tych sprawozdaniach informacje co najmniej o tym:

- do którego dnia wzięto pod uwagę informacje do analizy ich wpływu na sprawozdanie finansowe w związku z możliwością przesunięcia daty sporządzenia tego sprawozdania,

- czy wprowadzenie stanu epidemii uznano za zdarzenie po dniu bilansowym i zareagowano na nie w sposób wymagany regulacjami,

- czy wprowadzenie stanu epidemii już miało lub będzie miało istotne znaczenie w zakresie kontunuowania działalności,

- jaki jest wpływ na sprawozdanie finansowe i sytuację jednostki skutków wprowadzenia stanu epidemii i jakie informacje opisowe o tym się pojawiły.

Zbadano sprawozdania finansowe dwóch spółek, które sporządziły je w pierwotnym terminie, lecz jedna z nich już po ogłoszeniu stanu epidemii. Ponadto wzięto do badania sprawozdanie finansowe spółki, która skorzystała z możliwości przedłużenia terminu i opublikowała je prawie 2 miesiące po ogłoszeniu tego stanu. Wszystkie sprawozdania finansowe były zbadane przez biegłego

1 Regionalne podejście wynika z szerszych badań, jakie autor prowadzi odnośnie podmiotów właśnie w tym regionie, natomiast dostępność i format ograniczyły zakres badania, ponieważ czas na zamieszczenie plików nie upłynął w dacie analizowania, nie było dostępnej pełnej zbiorowości, a dodatkowo nie wszystkie podmioty umieściły pliki w formacie możliwym do odczytania. 
rewidenta, więc zapoznano się również ze sprawozdaniami z badania pod kątem potwierdzenia prawidłowości informacji zawartych w sprawozdaniach finansowych i zawartości informacji o wpływie skutków epidemii na sytuację jednostki. Celowo wzięto sprawozdania finansowe spółek akcyjnych, zakładając ich większy poziom jakości, również ze względu na badanie biegłego rewidenta. W każdym z nich szukano informacji o epidemii, odnotowując miejsce jej zamieszczenia, sposób zakwalifikowania, kompletność i spójność między informacją na ten temat podaną w różnych sprawozdaniach: finansowym, z działalności i z badania. Efekty zamieszczono w tabelach 1-3 dla każdej spółki osobno, a podsumowanie w tabeli 4.

Tabela 1. Zawartość informacji na temat stanu epidemii w sprawozdaniach Sefako S.A. sporządzonych 13 marca $2020 \mathrm{r}$.

\begin{tabular}{|l|l|l|}
\hline \multicolumn{1}{|c|}{ Sprawozdanie finansowe } & $\begin{array}{c}\text { Sprawozdanie } \\
\text { z działalności }\end{array}$ & $\begin{array}{c}\text { Sprawozdanie } \\
\text { z badania }\end{array}$ \\
\hline $\begin{array}{l}\text { Informacje dodatkowe - „40. Zdarzenia następujące } \\
\text { po dniu bilansowym. Po dniu bilansowym, a do dnia } \\
\text { zatwierdzenia sprawozdania finansowego nie wystąpiły } \\
\text { żadne istotne zdarzenia” }\end{array}$ & Brak informacji & Brak informacji \\
\hline
\end{tabular}

Źródło: opracowanie własne na podstawie sprawozdań za rok 2019, zamieszczonych na https://ekrs.ms.gov. $\mathrm{pl} / \mathrm{rdf} / \mathrm{pd} / \mathrm{search} \_\mathrm{df}$.

Pierwsza analizowana spółka, której dzień bilansowy przypadł przed ogłoszeniem stanu epidemii i która sporządziła sprawozdanie finansowe również przed wprowadzeniem tego stanu, nie zaprezentowała tego zdarzenia jako mającego istotny wpływ na jej obecne ani przyszłe wyniki, oczywiście według stanu wiedzy, jaki posiadała na dzień sporządzenia sprawozdania finansowego, czyli 13 marca. Pominięcie tematu epidemii można odczytać dwojako: albo jednostka nie miała wystarczających informacji o znaczeniu epidemii dla niej i nie brała jej pod uwage w analizie, albo uznała jej wpływ za nieistotny, a regulacje wymagają podania w tym przypadku tylko informacji o istotnym charakterze. Nie można z całą pewnością wnioskować na podstawie powyższych informacji, ponieważ w zaistniałej sytuacji nie są one jednoznaczne. Można przypuszczać, że 13 marca 2020 r. jednostka mogła wiedzieć o wydanych 8 marca 2020 r. przepisach dotyczących kwarantanny i hospitalizacji, ale nie musiała znać nawet planów ograniczeń epidemicznych (od 20 marca 2020 r.). Być może posiadała wystarczające i odpowiednie informacje, lecz nie uznała ich za istotne dla użytkownika sprawozdania finansowego do oceny jej sytuacji w przyszłości na tamten moment. Dlatego, jak należy to odczytać, punkt opisujący informacje o istotnych 
zdarzeniach, jakie nastąpiły po dniu bilansowym, stanowi oświadczenie, że takowych zdaniem jednostki nie było. Ustawa nie bez powodu ogranicza obowiązek podawania informacji do przypadku, gdyby mogły w istotny sposób wpłynąć na ocenę sytuacji majątkowej i finansowej oraz wynik finansowy. Pozwala to uniknąć nadmiaru informacji, dokonywania ujawnień „na wszelki wypadek”, żeby uniknąć odpowiedzialności za nieujawnienie, a jednocześnie umożliwia rozpoznanie tego, co ważne dla jednostki, a gdzie nie widzi ona znaczącego wpływu, a zatem poznanie podejścia zarządzających. Z zachowania zasady istotności wynika jakość sprawozdania finansowego i jednostka nie powinna zapełniać go informacjami nieistotnymi, a raczej „przefiltrować” je przez próg istotności (Wąsowski, 2005, s. 28).

Tabela 2. Zawartość informacji na temat stanu epidemii w sprawozdaniach Alma-Alpinex S.A. sporządzonych 24 marca $2020 \mathrm{r}$.

\begin{tabular}{|c|c|c|}
\hline Sprawozdanie finansowe & $\begin{array}{l}\text { Sprawozdanie } \\
\text { z działalności }\end{array}$ & $\begin{array}{c}\text { Sprawozdanie } \\
\text { z badania }\end{array}$ \\
\hline $\begin{array}{l}\text { Informacje dodatkowe: „33. Pod koniec } \\
2019 \text { r. po raz pierwszy pojawiły się } \\
\text { [wyróżnienie - M.G.] wiadomości z Chin } \\
\text { dotyczące koronawirusa. W pierwszych } \\
\text { miesiącach } 2020 \text { r. wirus rozprzestrzenił } \\
\text { się na całym świecie, a jego negatywny } \\
\text { wpływ nabrał dynamiki. Kierownictwo } \\
\text { uważa taką sytuację za zdarzenie nie po- } \\
\text { wodujące korekt w sprawozdaniu finan- } \\
\text { sowym za rok 2019, lecz za zdarzenie po } \\
\text { dacie bilansu wymagające dodatkowych } \\
\text { ujawnień. Chociaż w chwili publikacji } \\
\text { niniejszego sprawozdania finansowego } \\
\text { sytuacja ta wciąż się zmienia, do tej pory } \\
\text { kierownictwo jednostki nie odnotowało } \\
\text { zauważalnego wpływu na sprzedaż lub } \\
\text { łańcuch dostaw jednostki, jednak nie } \\
\text { można przewidzieć przyszłych skutków. } \\
\text { Kierownictwo podjęło już wszelkie możli- } \\
\text { we kroki, aby złagodzić negatywne skutki } \\
\text { dla jednostki wprowadzając odpowiednie } \\
\text { procedury pozwalające na zapewnienie } \\
\text { bezpieczeństwa i nadal będzie monitoro- } \\
\text { wać sytuację i podejmować odpowiednie } \\
\text { decyzje” }\end{array}$ & $\begin{array}{l}\text { Oświadczenie, że „poza } \\
\text { zdarzeniami opisanymi } \\
\text { w informacji dodatkowej, } \\
\text { po dniu bilansowym nie } \\
\text { wystąpiły żadne inne } \\
\text { zdarzenia, mające wpływ } \\
\text { na działalność Spółki i jej } \\
\text { sprawozdanie finansowe } \\
\text { za } 2019 \text { r." }\end{array}$ & $\begin{array}{l}\text { Objaśnienie ze zwróce- } \\
\text { niem uwagi - zdarzenie } \\
\text { po zakończeniu okresu } \\
\text { sprawozdawczego } \\
\text { "W pkt } 33 \text { informacji do- } \\
\text { datkowej do sprawozda- } \\
\text { nia finansowego Zarząd } \\
\text { Spółki przedstawił swoje } \\
\text { stanowisko w kwestii } \\
\text { istnienia lub nie zagro- } \\
\text { żenia dla kontynuacji } \\
\text { działalności Spółki w ak- } \\
\text { tualnej sytuacji epidemii } \\
\text { koronawirusa w kraju } \\
\text { i Europie" }\end{array}$ \\
\hline
\end{tabular}

Źródło: opracowanie własne na podstawie sprawozdań za rok 2019, zamieszczonych na https://ekrs.ms.gov. $\mathrm{pl} /$ rdf/pd/search_df. 
Kolejna spółka ustaliła datę sporządzenia sprawozdania finansowego już w stanie epidemii i we wszystkich sprawozdaniach znajduje się odniesienie do niego. Na jej dzień bilansowy stanu epidemii nie było, więc podobnie jak w przypadku poprzedniej spółki nie można się spodziewać tego, że sprawozdanie finansowe jest skorygowane o wpływ skutków epidemii. Potraktowała to zdarzenie - w jej przypadku mające miejsce po dniu bilansowym a przed dniem sporządzenia- jako istotne, o czym świadczy samo podanie informacji o nim w konkretnym miejscu sprawozdania finansowego, ale zdarzenie niekorygujące.

$Z$ podanych informacji wiadomo, że spółka ma na uwadze epidemię, nie odnotowała do chwili publikacji sprawozdania finansowego zauważalnego wpływu na jej działalność, ale zdaje sobie sprawę z niepewności i podejmuje działania, a także zapewnia czytelnika o monitorowaniu skutków tego zdarzenia. Wydaje się być to dość użyteczna informacja dla użytkownika, tym bardziej, że jest spójna ze sprawozdaniem z działalności i sprawozdaniem z badania, gdzie została również zawarta. Nie dochodzi ani do jej powielania (ma miejsce odesłanie), ani do uzupełniania o nowe treści. Po przeczytaniu sprawozdania finansowego czytelnik uzyskuje informację, jakiej wymaga ustawa.

Tabela 3. Zawartość informacji na temat stanu epidemii w sprawozdaniach Forbuild S.A. sporządzonych 22 maja $2020 \mathrm{r}$.

\begin{tabular}{|c|c|c|}
\hline Sprawozdanie finansowe & $\begin{array}{l}\text { Sprawozdanie } \\
\text { z działalności }\end{array}$ & $\begin{array}{c}\text { Sprawozdanie } \\
\text { z badania }\end{array}$ \\
\hline $\begin{array}{l}\text { Informacje dodatkowe Nota 35: } \\
\text { Informacje o znaczących zdarzeniach, jakie } \\
\text { nastąpiły po dniu bilansowym, a nie uwzględnio- } \\
\text { nych w sprawozdaniu finansowym. } \\
\text { W pierwszych miesiącach } 2020 \text { roku [wyróż- } \\
\text { nienie - M.G.] na świecie pojawił się nowy } \\
\text { negatywny czynnik, który niewątpliwie będzie } \\
\text { miał wpływ na gospodarki poszczególnych } \\
\text { krajów, w tym Polski. Szybko rozprzestrze- } \\
\text { niająca się epidemia koronawirusa COVID-19, } \\
\text { zbierająca ostatnio swoje negatywne żniwo na } \\
\text { rynkach finansowych, w najbliższym czasie } \\
\text { może odmienić dotychczasowe pozytywne } \\
\text { oblicze branży budowlanej i wpłynąć negatywnie } \\
\text { na sytuację Spółki i Grupy. Kierownictwo uważa } \\
\text { powstałą sytuację za zdarzenie nie powodujące } \\
\text { korekt w sprawozdaniu finansowym za rok 2019, } \\
\text { lecz za zdarzenie po dacie bilansu wymagające } \\
\text { dodatkowych ujawnień. } \\
\text { W ocenie Zarządu Spółki na dzień sporządzenia } \\
\text { sprawozdania finansowego sytuacja płynnościowa }\end{array}$ & $\begin{array}{l}\text { List Prezesa } \\
\text {,W związku z obecną sytuacją na } \\
\text { świecie spowodowaną epidemią } \\
\text { COVID } 19 \text { do najważniejszych } \\
\text { zadań na rok bieżący jakie so- } \\
\text { bie stawiamy jest utrzymanie na } \\
\text { obecnym poziomie przepływów } \\
\text { pieniężnych oraz zrealizowanie } \\
\text { sprzedaży w wysokości nie } \\
\text { mniejszej niż 80\% w stosunku } \\
\text { do roku 2019” } \\
\text { 7. Opis istotnych czynników } \\
\text { ryzyka i zagrożeń związanych } \\
\text { z otoczeniem } \\
\text { s. } 15 \text { „Ryzyko związane z epide- } \\
\text { mią koronowirusa } \\
\text { Na dzień publikacji niniejszego } \\
\text { raportu, zgodnie z najlepszą } \\
\text { wiedzą Zarządu Jednostki } \\
\text { dominującej, nie jest możliwe } \\
\text { precyzyjne określenie skutków }\end{array}$ & $\begin{array}{l}\text { Brak } \\
\text { informacji }\end{array}$ \\
\hline
\end{tabular}




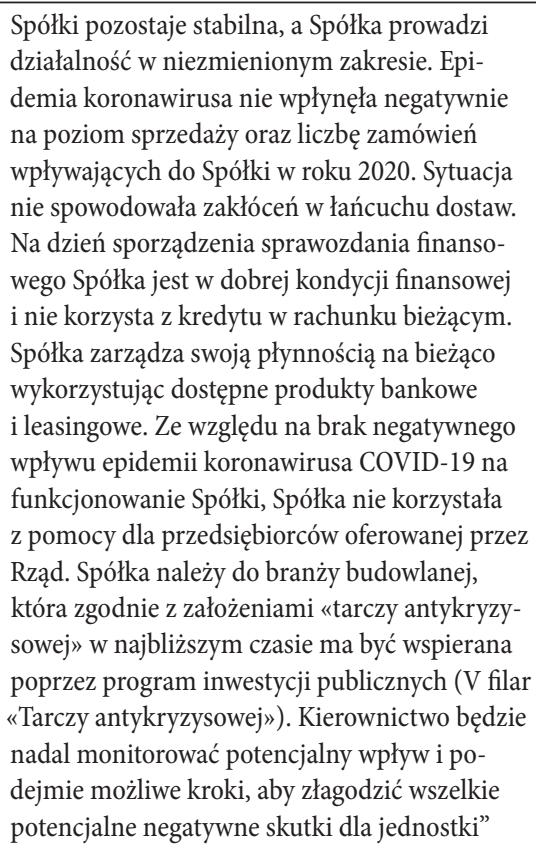

wpływu epidemii koronawirusa na działalność Spółki dominującej i grupy kapitałowej w perspektywie średnio- i długoterminowej. Szczegółowa informacja w zakresie wpływu epidemii na działalność Spółki i Grupy Kapitałowej została zaprezentowana w jednostkowym i skonsolidowanym sprawozdaniu finansowym w nocie 35 "

Źródło: opracowanie własne na podstawie sprawozdań za rok 2019, zamieszczonych na https://ekrs.ms.gov. $\mathrm{pl} / \mathrm{rdf} / \mathrm{pd} /$ search_df.

Ostatnie z analizowanych sprawozdań finansowych powstało już w stanie epidemii, na taki sam dzień bilansowy jak poprzednie. Między dniem ogłoszenia stanu epidemii a dniem sporządzenia minęły 2 miesiące. Informacja dotycząca epidemii pojawia się w sprawozdaniu finansowym i sprawozdaniu z działalności. Brak jest jej w sprawozdaniu $\mathrm{z}$ badania, czego przyczyn można upatrywać w założeniu, że biegły nie uznał za konieczne zwracanie uwagi na zdarzenie dobrze opisane w sprawozdaniu finansowym, oceniając informację tam zawartą za wystarczającą. Informacja tej jednostki jest najbardziej obszerna ze wszystkich i dotyka również wprowadzanej stopniowo pomocy państwa dla przedsiębiorców poszkodowanych na skutek epidemii. Samo badane zdarzenie uznano za niepowodujące korekt, a wymagające dodatkowych ujawnień. Przedstawiono opis najważniejszych kwestii odnośnie do wpływu na sytuację jednostki i zapewniono o jej monitorowaniu i gotowości przeciwdziałania negatywnym skutkom, odnosząc się również do kwestii państwowego wsparcia. Brak jest wyraźnego wskazania świadomości niepewności sytuacji, co zostało jasno wyrażone w liście w stwierdzeniu, że nie jest możliwe precyzyjne określenie skutków wpływu epidemii na działalność spółki. Pokazany jest tam też szacunkowy jej wpływ w postaci informacji o modyfikacji planów. Tym razem 
informacja zawarta w sprawozdaniu finansowym znajduje rozwinięcie w sprawozdaniu z działalności, a nawet można uznać, że ustawowy wymóg podania informacji o wpływie skutków epidemii na jednostkę jest sprecyzowany tamże.

Wszystkie spółki w zakresie kontynuacji działania zamieściły informację, że nie występuje niepewność co do możliwości kontynuowania działalności.

\section{Wyniki badań i wnioski}

W celu syntetycznego opisu ustaleń sporządzono zestawienie dat sprawozdań i zawartości informacyjnej. Można teraz powiązać pewne elementy i zauważyć, ile uwagi badanemu zagadnieniu poświęcono w poszczególnych sprawozdaniach. Dodać trzeba, że żaden $z$ biegłych rewidentów nie wydał opinii negatywnej czy z zastrzeżeniami, a w jednym przypadku miało miejsce wyłącznie zwrócenie uwagi na zagadnienie epidemii opisane w informacji dodatkowej, z odesłaniem do niej, bez oszacowania jego skutków.

Tabela 4. Informacje na temat stanu epidemii w sprawozdaniach badanych spółek podsumowanie

\begin{tabular}{|c|c|c|c|}
\hline $\begin{array}{l}\text { Spółka/Data } \\
\text { sporządzenia }\end{array}$ & $\begin{array}{l}\text { Sprawozdanie } \\
\text { finansowe }\end{array}$ & $\begin{array}{l}\text { Sprawozdanie } \\
\text { z działalności }\end{array}$ & $\begin{array}{l}\text { Sprawozdanie } \\
\text { z badania }\end{array}$ \\
\hline $\begin{array}{l}\text { SEFAKO } \\
13 \text { marca } 2020 \text { r. }\end{array}$ & $\begin{array}{l}\text { Zapis mówiący, że nie wystąpiły } \\
\text { żadne istotne zdarzenia }\end{array}$ & Brak informacji & Brak informacji \\
\hline $\begin{array}{l}\text { ALMA-ALPINEX } \\
24 \text { marca } 2020 \mathrm{r} .\end{array}$ & $\begin{array}{l}\text { Podane zdarzenie po dacie } \\
\text { bilansu z informacją o braku } \\
\text { dotychczas zauważalnego wpły- } \\
\text { wu epidemii i opisem podjętych } \\
\text { oraz planowanych działań }\end{array}$ & $\begin{array}{l}\text { Odesłanie do informa- } \\
\text { cji dodatkowej }\end{array}$ & $\begin{array}{l}\text { Zwrócenie uwagi } \\
\text { na zdarzenie opi- } \\
\text { sane w informa- } \\
\text { cji dodatkowej }\end{array}$ \\
\hline $\begin{array}{l}\text { FORBUILD } \\
22 \text { maja } 2020 \mathrm{r} \text {. }\end{array}$ & $\begin{array}{l}\text { Podane zdarzenie po dniu } \\
\text { bilansowym z informacją, że epi- } \\
\text { demia nie wpłynęła negatywnie, } \\
\text { spółka jest w dobrej kondycji } \\
\text { finansowej i będzie nadal moni- } \\
\text { torować sytuację }\end{array}$ & $\begin{array}{l}\text { Informacja o planach } \\
\text { i że nie jest możliwe } \\
\text { precyzyjne określenie } \\
\text { skutków wpływu } \\
\text { epidemii koronawirusa } \\
\text { na działalność spółki } \\
\text { w perspektywie średnio- } \\
\text { i długoterminowej. } \\
\text { Odesłanie do informa- } \\
\text { cji dodatkowej }\end{array}$ & Brak informacji \\
\hline
\end{tabular}

Źródło: opracowanie własne na podstawie sprawozdań za rok 2019, zamieszczonych na https://ekrs.ms.gov. $\mathrm{pl} / \mathrm{rdf} / \mathrm{pd} /$ search_df. 
Na podstawie analizy można powiedzieć, że:

- jedna spółka, która sporządziła sprawozdanie finansowe najwcześniej, przed dniem wprowadzenia stanu epidemii, a już po nałożeniu obowiązku kwarantanny, nie odnotowała wcale faktu epidemii ani pojawienia się wirusa; przeglądając jej sprawozdanie finansowe w oderwaniu od informacji o ówczesnej sytuacji gospodarczej, nie można dostrzec żadnego zagrożenia związanego z nadchodzącą epidemią;

- dwie spółki sporządzające sprawozdanie finansowe po dniu wprowadzenia stanu epidemii informują o wirusie, tylko jedna o epidemii, chociaż obie piszą już po dniu wprowadzenia stanu epidemii;

- dwie spółki sporządzające sprawozdanie finansowe po dniu wprowadzenia stanu epidemii stwierdzają, że epidemia jest to zdarzenie po dniu bilansowym niekorygujące sprawozdania finansowego;

- dwie spółki sporządzające sprawozdanie finansowe po dniu wprowadzenia stanu epidemii nie stwierdzają negatywnego (ani - jak należy sądzić - pozytywnego) wpływu epidemii na ich dotychczasową działalność, na prezentowane informacje; obie stwierdzają, że będą obserwować sytuację, aby złagodzić negatywne/potencjalnie negatywne skutki;

- jedna spółka - z branży budowlanej - sporządzająca sprawozdanie finansowe po dniu wprowadzenia stanu epidemii stwierdziła, że nie korzysta z pomocy państwa, chociaż branża ta została zaliczona do grupy objętej wsparciem „tarczy antykryzysowej”;

- jedna spółka sporządzająca sprawozdanie finansowe po dniu wprowadzenia stanu epidemii, sprawozdająca najpóźniej, opisała podejście do wsparcia;

- spółki używają zwrotów: „na dzień sporządzenia sprawozdania finansowego”, „w chwili publikacji niniejszego sprawozdania finansowego”, a zatem należy sądzić, że przeanalizowały sytuację do tego dnia,

- żadna spółka nie podała obszaru wpływu ani nie oszacowała przyszłych ewentualnych skutków epidemii, chociaż przywoływały sprzedaż, łańcuch dostaw, zamówienia, płynność; może to świadczyć o patrzeniu przez pryzmat kontynuacji działalności;

- jedna spółka w sprawozdaniu z działalności przyznała, że nie jest możliwe precyzyjne określenie skutków wpływu epidemii w perspektywie średnioi długoterminowej; nie znalazło się tam również określenie ich w krótkoterminowej perspektywie.

Jak widać, opisy i położenie ciężaru w poszczególnych dokumentach spółek są różne. Sprawozdanie finansowe sporządzone przed wprowadzeniem stanu epidemii nie zawiera informacji o niej. Spółki publikujące po dacie wprowadzenia 
stanu epidemii uznały za konieczne napisać o tym. Zrobiły tak, co w kontekście tego, że przepis wymaga, aby podać informacje tylko o istotnych zdarzeniach, sugerowałoby, iż jest to dla nich istotne. Ustawa o rachunkowości nie definiuje pojęcia istotności, a dokonuje tego sama jednostka. Powinna się ona kierować charakterem informacji (pojemność informacyjna) oraz jej materialnością (rząd wielkości) (Walińska, 2009, komentarz do art. 4) i brać pod uwagę potencjalny wpływ zdarzeń gospodarczych na sprawozdanie finansowe oraz cechy jego użytkowników, ponieważ to dla nich informacja ma być istotna przy podejmowaniu decyzji. Zdaniem Teresy Cebrowskiej (za Kaczmarczyk, 2011, s. 262) celem sprawozdania finansowego jest właśnie zaspokojenie potrzeb informacyjnych interesariuszy. Podanie informacji w tym punkcie pozwala zatem domniemywać, że uznano ją za istotną, czyli za taką, która wymaga ujawnienia z powodu wywierania istotnego wpływu.

Ponadto trzeba powiedzieć, że spółki poprawnie kwalifikują zdarzenie epidemii jako zdarzenie po dniu bilansowym, oświadczając to na prawidłową datę - dzień sporządzenia sprawozdania finansowego. Krótki okres od dnia wprowadzenia epidemii do dnia sporządzenia sprawozdania finansowego pozwala domniemywać, że jednostki rzeczywiście mogły nie doświadczać jeszcze jej negatywnego wpływu. Istotna jest informacja o zamiarze obserwowania sytuacji. Pewną formą prognozy może być stwierdzenie zawarte w liście prezesa zarządu mówiące, że:

W związku z obecną sytuacją na świecie spowodowaną epidemią COVID 19 do najważniejszych zadań na rok bieżący jakie sobie stawiamy jest utrzymanie na obecnym poziomie przepływów pieniężnych oraz zrealizowanie sprzedaży w wysokości nie mniejszej niż 80\% w stosunku do roku 2019 (FORBUILD, 2019, s. 3).

Jest ono tak sformułowane, jakby wzięto już pod uwagę wpływ epidemii i obniżono pierwotne plany wyników, czyli uwzględniono w nich wpływ epidemii. Jednocześnie nie zamieszczono takiej informacji w samym sprawozdaniu finansowym.

Czy w świetle powyższego można powiedzieć, że informacje dotyczące przedmiotowego zagadnienia są użyteczne? Użyteczność informacji rachunkowości o działalności gospodarczej jest funkcją szczegółowości sprawozdań finansowych i jej zapewnienie wymaga, aby informacje były oczekiwane i przydatne (Gmytrasiewicz, 2008, s. 38 i 96). Jednostki wypełniły obowiązki i oświadczyły, że nie występuje niepewność co do możliwości kontynuowania działalności, 
sygnalizując niepewność (w przypadku sprawozdań finansowych sporządzonych po dacie ogłoszenia stanu epidemii) odnośnie do wpływu skutków obecnego kryzysu. Patrząc z punktu widzenia sporządzającego, hipoteza nie została zatem potwierdzona. Trzeba jednak zastanowić się nad tym, jak użytkownik odczytuje taką informację i wydaje się, że jej odczytanie przez niego może być różne, a zatem nie da się jednoznacznie potwierdzić hipotezy. Jednostki, mimo stwierdzenia w jednej części sprawozdania finansowego w sposób niebudzący wątpliwości swojej zdolności do kontynuowania działalności, w innymi miejscu zaznaczają - całkiem słusznie - niepewność w tym względzie wynikającą z trwającego kryzysu. Niejednoznaczność wydźwięku tej informacji dla użytkownika może wynikać $\mathrm{z}$ faktu, że należy brać pod uwagę, w jakich warunkach gospodarczych, politycznych, społecznych, branżowych sporządzone było sprawozdanie finansowe, a następnie porównać je z tymi na dzień analizy (Błażyńska, 2015, s. 141). Zatem informacja oceniana może być nie tylko przez fakt jej podania i sposobu uczynienia tego, lecz także w kontekście okoliczności, w jakich została przygotowana (dzień sporządzenia) i w jakich podejmuje się decyzje (dzień odczytania), co w sytuacji trwającego globalnego kryzysu ma szczególne znaczenie. Prawdopodobnie, co wymagałoby zbadania, z winy obiektywnych ograniczeń, które utrudniają formułowanie ostatecznych stwierdzeń w czasie kryzysu, informacja może dla czytelnika mieć ograniczoną użyteczność. W kolejnych okresach trwania epidemii, mimo coraz większej liczby informacji, nie musi być ani łatwiej sporządzać sprawozdanie finansowe, ani je odczytać ze względu na niemalejący stopień niepewności i zmienność sytuacji. Odniesienie się do sposobu przyjmowania i oceny informacji przez użytkownika zmierzałoby m.in. do wykorzystania dorobku finansów behawioralnych w rachunkowości, gdyż ten pomógłby w ocenie, jak też w zwiększeniu użyteczności informacji (Masztalerz, 2010, s. 41-56).

Badanie, w związku z pojawiającymi się w jego trakcie pytaniami, doprowadziło również do identyfikacji potrzeby pogłębionych i złożonych badań w różnych obszarach. Przykładowo, analizując sprawozdania finansowe większej liczby jednostek, można byłoby ustalić, czy wykształciła się praktyka informowania o tym konkretnym kryzysie i jaka ona jest. Można również badać, czy w ogóle - nie tylko w zakresie informacji o przyszłości - sprawozdania finansowe sporządzane w czasie kryzysu gospodarczego spełniają wymóg użyteczności. 


\section{Zakończenie}

Użyteczność sprawozdań finansowych jest pochodną ich przydatności i wiarygodności, jest także uzależniona od potrzeb informacyjnych ich użytkowników (Wierzbińska, 2014, s. 158), które mogą być szczególne w czasie kryzysu. Przeprowadzone badanie pozwoliło ustalić, że w analizowanych przykładowych sprawozdaniach finansowych można znaleźć informacje powstałe w związku z epidemią występujące w różnej ilości i szczegółowości w zależności od tego, kiedy zostały one sporządzone względem daty ogłoszenia stanu epidemii. Jednostki, które sporządzały sprawozdanie finansowe po tej dacie, opisały wprowadzenie stanu epidemii jako zdarzenie po dniu bilansowym niekorygujące sprawozdania finansowego. Każda podała tę informację z inną szczegółowością. Można z niej dowiedzieć się, że w okresie sporządzania sprawozdań spółki nie odczuły skutków stanu epidemii i nie widziały niepewności w zakresie kontunuowania działalności. Warto zobaczyć, co jest zamierzeniem autora, jak to będzie wyglądać za rok, kiedy problemy skutków epidemii uwidocznią się z większą ostrością. Wtedy ujawnią się one również w danych finansowych, a ,inwestorzy opierają się raczej na samych liczbach niż na zawartości informacyjnej" (Hendriksen, Van Breda, 2002, s. 192193). Warto też analizować czynniki determinujące sposób i zakres ujawnień w sprawozdaniach finansowych, ponieważ są one podstawowym, a w wielu przypadkach zweryfikowanym przez biegłego rewidenta, źródłem informacji ujawnianych jako oświadczenie jednostki. Sytuacja epidemii wzbudza ogólną niepewność, również informacyjną. Ważne jest „Zwłaszcza odpowiednio wczesne rozpoznawanie głównych czynników kryzysowych i wczesne ostrzeganie przed zagrożeniami w działalności gospodarczej” (Mączyńska, 2011, s. 24). Tymczasem

ocena zdolności jednostki do kontynuacji działania wymaga przeprowadzenia kompleksowych analiz ekonomiczno-finansowych, których źródłem i gwarantem powinny być zatwierdzone przez jednostkę plany strategiczne oraz funkcjonujące $w$ jednostce narzędzia kontroli i wspomagania ich realizacji (Walińska, 2009, komentarz do art. 5 ust. 2).

Oczywiście na zawartość informacyjną sprawozdania finansowego wpływa wiele innych czynników, w tym behawioralne, dlatego wydaje się, że cenna byłaby dodatkowa informacja ze strony jednostki, udostępniona według zapotrzebowania interesariuszy, wyjaśniająca określone zapisy i weryfikująca domysły. Znaczenia nabiera w tym kontekście sprawozdanie z badania, w którym znajduje się opinia wyrażona przez niezależnego autora mającego dostęp do jednostki i jej doku- 
mentów. Natomiast w zakresie samej analizy danych finansowych, szczególnie porównawczej, konieczne jest umiarkowanie i ostrożność w ocenach, zapewne jeszcze w kolejnym, dla większości jednostek de facto pierwszym roku obrotowym uwzględniającym skutki epidemii. Dla samych jednostek ważne jest zaś, że zainteresowanie problematyką zmniejszania ryzyka i ochrony przed upadkiem wykazują nie tylko pojedyncze podmioty i organizacje, lecz także rządy i instytucje międzynarodowe (Sasin, 2011, s. 121). Aktualna w nauce i praktyce rachunkowości staje się zatem problematyka uwzględnienia w sprawozdawczości prawdopodobnych skutków sytuacji kryzysowych o charakterze globalnym dla sytuacji finansowej przedsiębiorstwa, czy szerzej - kwestia użyteczności sprawozdań finansowych sporządzanych w czasie trwania kryzysów gospodarczych.

\section{Bibliografia}

\section{Akty prawne}

Ustawa z dnia 2 marca 2020 r. o szczególnych rozwiązaniach związanych z zapobieganiem, przeciwdziałaniem i zwalczaniem COVID-19, innych chorób zakaźnych oraz wywołanych nimi sytuacji kryzysowych, Dz.U. 2020, poz. 374. Pobrano z http:// isap.sejm.gov.pl/isap.nsf/DocDetails.xsp?id=WDU20200000374 (18.08.2020).

Ustawa z dnia 29 września 1994 r. o rachunkowości, Dz.U. 1994, nr 121, poz. 591. Pobrano z http://isap.sejm.gov.pl/isap.nsf/DocDetails.xsp?id=WDU19941210591 (18.08.2020).

Rozporządzenie Ministra Zdrowia z dnia 20 marca 2020 r. w sprawie ogłoszenia na obszarze Rzeczypospolitej Polskiej stanu epidemii, Dz.U. 2020, poz. 491. Pobrano $\mathrm{z}$ https://isap.sejm.gov.pl/isap.nsf/DocDetails.xsp?id=WDU20200000491 (18.08.2020).

Rozporządzenie Ministra Finansów z dnia 31 marca 2020 r. w sprawie określenia innych terminów wypełniania obowiązków w zakresie ewidencji oraz w zakresie sporządzenia, zatwierdzenia, udostępnienia i przekazania do właściwego rejestru, jednostki lub organu sprawozdań lub informacji, Dz.U. 2020, poz. 570. Pobrano $\mathrm{z}$ https://isap.sejm.gov.pl/isap.nsf/DocDetails.xsp?id=WDU20200000570 (18.08.2020).

\section{Literatura}

Alma-Alpinex S.A. (2019). Sprawozdanie finansowe, sprawozdanie niezależnego biegłego rewidenta, sprawozdanie z działalności Alma-Alpinex S.A. za okres od 01 stycznia 2019 r. do 31 grudnia 2019 r. Pobrano z https://ekrs.ms.gov.pl/rdf/pd/search_df (27.08.2020). 
Błażyńska, J. (2015). Użyteczność informacji finansowych sprawozdań finansowych. Poznań: Wydawnictwo Uniwersytetu Ekonomicznego w Poznaniu.

FORBUILD. (2019). Sprawozdanie finansowe, sprawozdanie niezależnego biegłego rewidenta, sprawozdanie z działalności FORBUILD S.A. za okres od 01 stycznia 2019 r. do 31 grudnia 2019 r. Pobrano z https://ekrs.ms.gov.pl/rdf/pd/search_df (27.08.2020).

Gmytrasiewicz, M. (2008). Rachunkowość. Podstawowe założenia i zasady. Warszawa: Difin.

Hendriksen, E.A., Van Breda, M.F. (2002). Teoria rachunkowości (red. A.A. Jaruga, tłum. G. Idzikowska). Warszawa: Wydawnictwo Naukowe PWN.

Kaczmarczyk, A. (2011). Sprawozdawczość finansowa a koncepcja wiernego i rzetelnego obrazu. W: Pracownicy Katedry Rachunkowości Szkoły Głównej Handlowej w Warszawie (red.), Rachunkowość, sztuka pomiaru i komunikowania (ss. 257265). Warszawa: Oficyna Wydawnicza SGH.

Komunikat Ministra Finansów w sprawie ogłoszenia uchwały Komitetu Standardów Rachunkowości w sprawie przyjęcia aktualizacji Krajowego Standardu Rachunkowości Nr 7 „Zmiany zasad (polityki) rachunkowości, wartości szacunkowych, poprawianie błędów, zdarzenia następujące po dniu bilansowym - ujęcie i prezentacja” (2019, 4 stycznia). Pobrano z https://www.gov.pl/web/finanse/krajowe-standardy-rachunkowosci (18.08.2020).

Masztalerz, M. (2010). Użyteczność sprawozdań finansowych dla inwestorów giełdowych w świetle finansów klasycznych i behawioralnych. Zeszyty Teoretyczne Rachunkowości, 57(113), 41-55.

Mączyńska, E. (red.). 2011. Cykle życia i bankructwa przedsiębiorstw. Warszawa: Oficyna Wydawnicza SGH.

SEFAKO. (2019). Sprawozdanie finansowe, sprawozdanie niezależnego biegłego rewidenta, sprawozdanie z działalności Fabryki Kotłów SEFAKO Spółka Akcyjna S.A. za okres od 01 stycznia 2019 r. do 31 grudnia 2019 r. Pobrano z https://ekrs.ms.gov. $\mathrm{pl} / \mathrm{rdf} / \mathrm{pd} /$ search_df $(27.08 .2020)$.

Sasin, R. (2011). Zarządzanie zintegrowanym ryzykiem a cykl życia przedsiębiorstwa. W: E. Mączyńska (red.), Cykle życia i bankructwa przedsiębiorstw (ss. 121-137). Warszawa: Oficyna Wydawnicza SGH.

Wierzbińska, Z. (2014). Wycena aktywów i pasywów a oczekiwania informacyjne użytkowników sprawozdań finansowych. Studia Oeconomica Posnaniensia, 2(4), 150-164.

Walińska, E. (red.). (2009). Komentarz do ustawy z dnia 29 września 1994 r. o rachunkowości, Polska: LEX 2009.

Wąsowski, W. (2005). Kreatywna rachunkowość. Fałszowanie sprawozdań finansowych. Warszawa: Difin. 


\section{Streszczenie}

Wprowadzenie stanu epidemii w Polsce wywołało określone konsekwencje w rachunkowości. Dokonano wydłużenia terminu sporządzenia sprawozdania finansowego. Zdarzenie ogłoszenia stanu epidemii mogło mieć miejsce w okresie po dacie bilansu. Jednostki powinny analizować zdarzenia po dacie bilansu, ocenić i zakwalifikować jako istotne lub nie, korygujące lub nie, wymagające ujawnienia w nim w formie opisowej lub nie. Pytaniem badawczym jest, jak jednostki odnotowały ogłoszenie epidemii w związku z zakażeniami wirusem SARS-CoV-2 i wynikające z tego kolejne zdarzenia w sprawozdaniu finansowym. Postawiono pytanie o użyteczność informacji w sprawozdaniu finansowym. Obiektem badań były przykładowe sprawozdania finansowe, gdzie szukano informacji o wpływie sytuacji epidemicznej na sytuację majątkowo-finansową i wynik finansowy, a także potwierdzenia wypełnienia wymogów regulacji. Badania krytyczne regulacji i literatury przedmiotu oraz sprawozdań i wnioskowanie metodą indukcji i dedukcji pozwoliły na dobrą ocenę wypełnienia obowiązków i na kilka wstępnych wniosków, wymagających jednak dalszych badań. Narracyjne zapisy dotyczące sytuacji jednostki w związku ze stanem epidemii mogą być różnie zinterpretowane i zależą od tego, na jaki dzień i kiedy jednostki sporządzają sprawozdanie finansowe względem dnia ogłoszenia stanu epidemii. Ich pełne zrozumienie wymagałoby dodatkowych wyjaśnień ze strony jednostki. Użytkownicy sprawozdań finansowych powinni liczyć na społeczną odpowiedzialność jednostek, dla których sytuacja epidemii jest praktycznym sprawdzianem.

SŁOWA KLUCzowE: rachunkowość, sprawozdawczość, SARS-CoV-2.

\section{Summary}

The introduction of the state of epidemic in Poland had certain consequences for accounting. The deadline for preparing the financial statement has been extended. The announcement theepidemic may have occured in the period after the balance sheet date. Entities should analyse events after the balance sheet date, evaluate and determine whether they are essential, corrective to the statement, requiring disclosure in a descriptive form or not. The research question is: how did individual units record the announcement of the state of epidemic in connection with SARS-CoV-2 infection and the resulting events in the financial statements. The question was asked about the usefulness of the information in the financial statement. The study included sample financial reports where information was sought on the impact of the epidemiological situation on the financial situation and financial performance, as well as confirmation of compliance with the regulatory requirements.

Critical analysis of the regulations, literature on the subject and the statements, as well as the employment of induction and deduction method have allowed a good assessment of the fulfillment of duties and a few preliminary conclusions, however, requiring further research. The narrative records of an entity's position in relation to the outbreak of the epidemic can be interpreted differently, depending on what date and when the entity prepares a financial statement relative to the date on which the outbreak was announced. 
Its full understanding would require additional explanations from the entity. Users of the financial statements should count on the social responsibility of entities, for whom the state of epidemic is a practical test.

KEYwords: accounting, reporting, SARS-CoV-2.

\section{Nota o Autorze}

Małgorzata Garstka - dr; Uniwersytet Jana Kochanowskiego w Kielcach; główny obszar działalności naukowej: rachunkowość; e-mail: malgorzata.garstka@ujk.edu.pl; ORCID: 0000-0002-0971-0274. 